Vol 2. No 1. Februari 2018

ISSN 2580-5029

\title{
PEMANFAATAN, PERSEPSI, \& PARTISIPASI MASYARAKAT TERHADAP PELESTARIAN POHON DI SEKITAR GARIS IMAJINER KRATON YOGYAKARTA
}

\author{
Hendro kusumo Eko Prasetyo Moro ${ }^{1^{*}}$ \\ 1Universitas Ahmad Dahlan, Yogyakarta, Indonesia \\ *Email: morosmart@yahoo.com
}

\begin{abstract}
Ecological studies related to socio-economic and community roles in imaginary line of the Sultan's Palace need to be undertaken to design a proper management and conservation model. The purpose of this study is to examine the perception and participation of the community in the effort of preserving the trees around the imaginary line of the Sultan's Palace, as well as its supporting and inhibiting factors. The research conducted from April 2017 to November 2017. Data collection was done by observation and interview. Data processing is done by interpretation analysis using related reference. The results show that people's perception of trees around the imaginary line of their existence is very important, needs to be maintained, and preserved in order to function properly. Forms of community participation include maintaining the sustainability of the trees by replanting the fallen, nurturing, and not doing destructive activities. Product of trees around the imaginary line like fruit and wood are not entirely usable. Supporting factors are local wisdom, active role, and cooperation with stakeholders \& local government. Factors inhibiting the economic function of trees around the imaginary line is less, knowledge of human resources is still low, and the responsibility of the region is less clear due to the absence of good preservation procedures. The conclusion of this research is the perception and participation of the community to support the effort of preserving the trees around the imaginary line of Kraton Yogyakarta.
\end{abstract}

Keywords: Perception, Conservation, Imaginary Line, Kraton Yogyakarta

\begin{abstract}
ABSTRAK
Kajian ekologi berkaitan dengan sosial ekonomi dan peran masyarakat memanfaatkan sumberdaya vegetasi di sekitar garis imajiner Kraton Yogyakarta perlu dilakukan untuk merancang model pengelolaan dan pelestarian yang benar. Tujuan penelitian ini mengkaji persepsi dan partisipasi masyarakat dalam upaya pelestarian pohon sekitar garis imajiner Kraton Yogyakarta, serta faktor pendukung dan penghambatnya. Penelitian berlangsung pada April 2017 hingga November 2017, di sekitar garis imajiner Kraton Yogyakarta. Pengumpulan data dilakukan dengan observasi dan wawancara. Pengolahan data dilakukan analisa interpretasi dengan menggunakan referensi terkait. Hasil penelitian menunjukkan bahwa persepsi masyarakat tentang pohon-pohon sekitar garis imajiner keberadaannya sangat penting, perlu dijaga, dan dilestarikan supaya berfungsi sebagaimana mestinya. Bentuk partisipasi masyarakat diantaranya adalah menjaga keberlangsungan pohon-pohon dengan menanam kembali yang tumbang, memelihara, serta tidak melakukan kegiatan yang merusak. Hasil pohon sekitar garis imajiner berupa buah dan kayu tidak seluruhnya dapat dimanfaatkan. Faktor pendukung yaitu adanya kearifan lokal, peran aktif, dan kerjasama kraton dengan stakeholders maupun pemerintah kota setempat. Faktor penghambat yaitu fungsi ekonomi
\end{abstract}


pohon sekitar garis imajiner kurang, pengetahuan sumber daya manusia masih rendah, dan penanggung-jawab wilayah kurang jelas akibat belum adanya prosedur pelestarian yang baik. Kesimpulan dari penelitian ini adalah persepsi dan partisipasi masyarakat mendukung upaya pelestarian pohon-pohon di sekitar garis imajiner Kraton Yogyakarta.

Kata kunci : Persepsi,Partisipasi, Garis imajiner, Kraton Yogyakarta

\section{PENDAHULUAN}

Kraton Yogyakarta dibangun sejak 9 Oktober 1755, oleh Pangeran Mangkubumi sekaligus menjadi Sri Sultan Hamengku Buwono I (Djoko Soekirman, dkk., 1996). Pohon-pohon di sekitar garis imajiner Kraton Yogyakarta dari Tugu Jogja hingga Panggung Krapyak hakekatnya seperti keberadaan hutan kota, perlu dilestarikan untuk mendukung upaya konservasi (etnokonservasi), tanaman (etnobotani), dan tata air yang mencegah banjir, erosi, menjaga kesuburan tanah, serta menjadi penyangga kehidupan masyarakat (Suparmoko, 1997).

Di zaman reformasi eksistensi dan keistimewaan Kraton Yogyakarta diuji kembali dengan gejolak politik berskala nasional (Luthfi, dkk., 2009). Pihak kraton tercatat beberapa kali menyelenggarakan Pisowanan Ageng mulai bulan Mei 1998 saat puncak akumulasi dari proses gerakan reformasi di Indonesia, hingga sembilan tahun 6 bulan setelahnya. Sultan menyelenggarakan Pisowanan Ageng IV pada 28 Oktober 2008 dimana Sultan Hamengku Buwono X menyatakan statement kesiapan untuk dicalonkan sebagai Presiden pada pemilu 2009. Sekitar tahun 2010 sampai 2017 ontran-ontran akibat sabda raja dan sabda tama tentang rencana pengangkatan sultan perempuan dan perubahan gelar buwono-bawono berdampak pada berbagai bidang kehidupan di kraton. Perubahan perhatian dan kebijakan akan membawa dampak kepada pemanfaatan, persepsi dan partisipasi pelestarian tanaman (termasuk pohon) di sekitar garis imajiner Kraton Yogyakarta.

Kegiatan komersial juga berpengaruh terhadap perubahan fungsi lingkungan. Untuk itu diperlukan suatu upaya pelestarian berkelanjutan yang nyata juga ditentukan jenis kegiatan pelestarian yang tepat (Murti, C. dan H.B. Wijaya, 2013)

Untuk pengelolaan kawasan sekitar garis imajiner Kraton Yogyakarta berkelanjutan diperlukan studi mengenai persepsi dan partisipasi serta faktor-faktor yang mendukung dan menghambat upaya masyarakat dalam pelestarian pohon di sekitarnya.

Penelitian ini bertujuan untuk mengkaji persepsi dan partisipasi masyarakat dalam upaya pelestarian pohon sekitar garis imajiner Kraton Yogyakarta, serta faktor pendukung dan penghambatnya.

\section{METODE}

Penelitian berlangsung pada April 2017 hingga November 2017, bertempat di sekitar 
garis imajiner Kraton Yogyakarta, dari Tugu Jogja hingga Panggung Krapyak (Gambar 1) sesuai Perda. DIY No 4 tahun 2011, yakni dari Tugu Yogyakarta, sampai Panggung Krapyak. makna kosmologis. Hutan Beringan terletak di tengah-tengah antara Laut Selatan dan Gunung Merapi. Poros Merapi-Kraton-Laut Selatan menunjukkan sebuah lanskap untuk

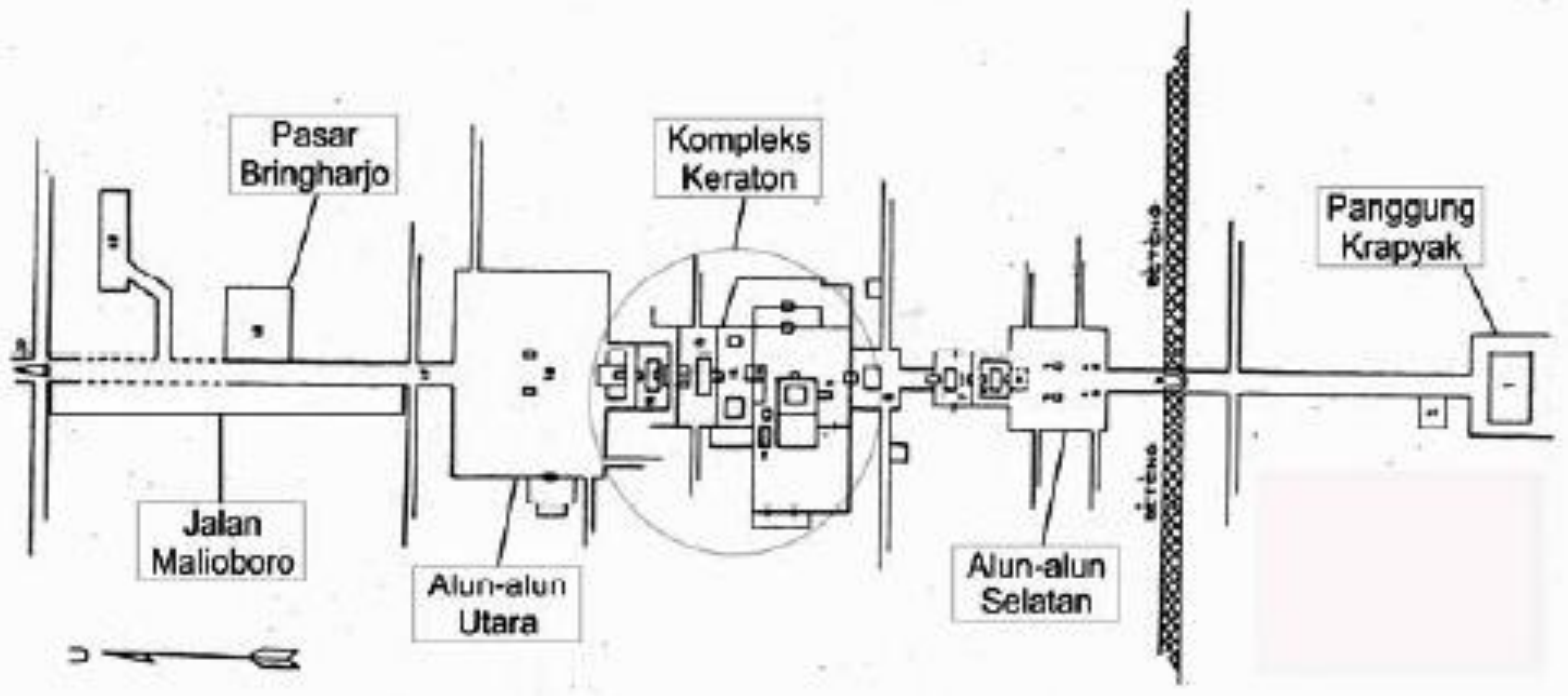

Gambar 1. Garis Imajiner Kraton Yogyakarta Sumber: diadaptasi dari Datasolusindo, 2011

Penelitian ini menggunakan pendekatan kualitatif dengan metode field research (penelitian lapangan). Field research secara langsung bersentuhan dengan fenomena sosial yang diteliti. Pengumpulan data dilakukan dengan observasi dan wawancara mendalam. Pemilihan informan dalam penelitian menggunakan teknik purposive sampling. Pengolahan data secara tabulasi, selanjutnya dilakukan analisa interpretasi dengan menggunakan referensi terkait menggunakan metode emik dan etik serta literatur yang berhubungan dengan masalah penelitian (Ferguson, G.A., 1991).

\section{HASIL DAN PEMBAHASAN}

Lokasi Kraton Yogyakarta dahulu merupakan Hutan Beringan mempunyai menyelaraskan kehidupan di bumi. Maknanya supaya masyarakat menjaga lingkungan yang disampaikan leluhur melalui wejangan dan nasihat secara turun-temurun (Darmawan, 2010). Secara geografis Kraton Yogyakarta terletak pada koordinat 110²1'872” BT - 110²1'786" BT dan 07०48'177" LS - 07048'754" LS.

Seperti kraton lainnya, secara umum pohon-pohon di Kraton Yogyakarta asalnya bertumpu pada konsep bersatunya manusia dengan Tuhannya (Brongtodiningrat, 1978), sehingga jenis, jumlah, dan letaknya tidak sembarangan ditanam.

Pada penelitian ini persepsi masyarakat di sekitar garis imajiner Kraton Yogyakarta umumnya mengerti dengan keberadaan pohon-pohon di sekitar garis imajiner. Persepsi masyarakat tentang pohon-pohon 
sekitar garis imajiner keberadaannya sangat penting, perlu dijaga, dan dilestarikan supaya berfungsi sebagaimana mestinya. Bentuk partisipasi masyarakat diantaranya adalah menjaga keberlangsungan pohon-pohon dengan menanam kembali yang tumbang, memelihara, serta tidak melakukan kegiatan yang merusak.

Hasil pohon sekitar garis imajiner berupa buah dan kayu tidak seluruhnya dapat dimanfaatkan. Hanya masyarakat sekitar dan abdi dalem yang secara aktif berpartisipasi dalam kegiatan perawatan dengan belum adanya prosedur yang mengatur pelestarian lngkungan.

Pelestarian tidak bertahan dan berkembang (sustainable) jika tidak ada dukungan masyarakat luas. Pelestarian harus hidup dan berkembang di masyarakat sekitar garis imajiner. Pelestarian harus diperjuangkan oleh masyarakat luas (Hadiwinoto, 2002) bukan hanya tanggung jawab abdi dalem atau pemerintah kota Yogyakarta saja.

Hasil penelitian ini sesuai dengan penelitian Wastuty (2007) di Kawasan Siliran Lor, dimana pohon di sekitar kawasan Kraton semakin beragam dengan munculnya bermacam jenis baru. Pemanfaatan pohon di kawasan ini masih mempertahankan nilai filosofinya. Beberapa wilayah seperti : kawasan Malioboro, kawasan Panggung Krapyak, dan Kemandungan sudah meninggalkan sisi filosofisnya, dan mengutamakan fungsi pohon sebagai peneduh, konsumtif, dan kesehatan.
Menurut Moro (2017) ada 16 jenis pohon yang masih memiliki nilai filosofis terkait garis imajiner Kraton Yogyakarta. Tujuan pohon-pohon tersebut ditanam oleh masyarakat umum masih dianggap supaya lingkungan asri dan peneduh saja.

Persepsi masyarakat yang sudah mengerti makna filosofis pohon di sekitar garis imajiner Kraton Yogyakarta tidak didukung partisipasi dan pemanfaatan dengan prosedur yang baik dan jelas. Pemanfaatan dan pemeliharaan pohon di beberapa wilayah garis imajiner dilakukan oleh pihak berbeda. Di wilayah Panggung Krapyak dan Tugu Jogja sampai Alun-Alun Utara menjadi tanggung jawab pemerintah kota. Untuk wilayah kraton, sebenarnya telah ada abdi dalem yang bertanggung jawab untuk perawatan tanaman. Mereka bertindak atas perintah salah satu adik Sultan. Wilayah yang sangat terpelihara misalnya: lingkungan kraton sendiri, Keben, dan Kemagangan, namun wilayah Kemandungan tanggungjawabnya seolah terbagi dua antara abdi dalem abrit yang kurang aktif dan masyarakat yang tinggal di sekitarnya. Wilayah Alun-alun Selatan bahkan secara nyata dikelola oleh pedagang kaki lima (PKL) dalam koordinasi tertentu. Kenyataan ini tentu saja menyulitkan dalam merancang program dan langkah teknis pelestarian di sekitar garis imajiner jangka panjang

Faktor pendukung pelestarian dan partisipasi masyarakat yaitu adanya kearifan lokal, peran aktif, dan kerjasama Kraton dengan stakeholders, dan pemerintah kota, 
sedangkan faktor penghambatnya yaitu persepsi fungsi ekonomi pohon sekitar garis imajiner kurang, pengetahuan sumber daya manusia dalam pengelolaan pelestarian masih rendah, dan penanggung-jawab wilayah kurang jelas akibat belum adanya prosedur pelestarian. Hal ini terlihat dalam perbedaan presepsi pelestarian pohon di sekitar garis imajiner.

Menurut Mukhlison (2013) di kawasan perkotaan Yogyakarta ada 112 jenis pohon, 70 jenis di antaranya dinyatakan sesuai dengan persyaratan silvikultural, manajemen dan estetika. Diantara jenis tersebut terdapat 22 jenis pohon tempat tumbuhnya sesuai dan efektif mengendalikan pencemaran udara, seperti: Bungur (Lagerstroemia speciosa), Angsana (Pterocarpus indicus), dan Mahoni (Swietenia macrophylla). Dari ketiga jenis tersebut tidak ada satupun yang menjadi pohon bernilai filosofis untuk ditanam di sekitar garis imajiner Kraton Yogyakarta.

\section{SIMPULAN}

Persepsi dan partisipasi masyarakat mendukung upaya pelestarian pohon-pohon di sekitar garis imajiner Kraton Yogyakarta.

Masyarakat memandang keberadaan pohonpohon sekitar garis imajiner sangat penting, perlu dijaga, dan dilestarikan. Bentuk partisipasi masyarakat diantaranya terbatas menjaga kebersihannya. Hanya masyarakat sekitar dan abdi dalem tertentu yang aktif berpartisipasi dalam kegiatan perawatan.

\section{UCAPAN TERIMA KASIH}

Penelitian ini dapat dilaksanakan melalui biaya dari LPP UAD tahun anggaran 20162017. Ucapan terima kasih disampaikan kepada seluruh pihak yang telah membantu terlaksananya penelitian ini, khususnya pihak Kraton Yogyakarta, Pemerintah Kota Yogyakarta dan seluruh mahasiswa mata kuliah etnobiologi Pendidikan Biologi FKIP UAD tahun 2017.

\section{DAFTAR PUSTAKA}

Anonim. 2011. Peraturan Daerah Provinsi Daerah Istimewa Yogyakarta Nomor 4 tentang Tata Nilai Budaya Yogyakarta.

Brongtodiningrat. 1978. Arti Kraton Yogyakarta. Museum Kraton Yogyakarta. Yogyakarta.

Darmawan. 2010. Belajar Green dari Kearifan Lokal. dalam http://www.kompasiana.com/posts/ty pe/opinion/. diunduh 22 Januari 2017.

Djoko Soekirman, 1986. Sejarah Kota Yogyakarta. Jakarta: Direktorat Sejarah dan Nilai Tradisional, Dirjen Kebudayaan, Depdikbud RI.

Ferguson, George A. 1991. Statistical Analysis in Psychology and Education. Auckland: Mc.Graw Hill, International Book Company.

Hadiwinoto, S. 2002. Beberapa Aspek Pelestarian Warisan Budaya. Makalah disampaikan pada Seminar Pelestarian dan Pengembangan Masjid Agung Demak, di Demak, pada tanggal 17 Januari 2002.

Luthfi, A.N., M. Nazir, A. Tohari, D.A. Winda, D.C. Tristiawan. 2009. Keistimewaan Yogyakarta: yang diingat dan dilupakan. Sekolah Tinggi Pertanahan Nasional. Yogyakarta. 
Moro, H.K.E.P., 2017. Studi Etnobotani \& Upaya Pelestarian Tanaman di Sekitar Kraton Yogyakarta. Prosiding Sendika FKIP UAD. Yogyakarta.

Mukhlison. 2013. Pemilihan Jenis POhon untuk Pengembangan Hutan Kota di Kawasan Perkotaan Yogyakarta. Jurnal Ilmu Kehutanan.Volume VII No. 1 Januari-Maret 2013.

Murti, C. dan H.B. Wijaya. 2013. Pengaruh Kegiatan Komersial terhadap Fungsi Bangunan Bersejarah di Koridor Jalan Malioboro Yogyakarta. Jurnal Teknik PWK. Volume 2 Nomor 12013 hal. 6075.

Suparmoko. 1997. Ekonomi Sumberdaya Alam dan Lingkungan, Penerbit BPFE Yogyakarta,

Wastuty, P.W.2007. Eko Arsitektur pada Kawasan Siliran Lor Tinjauan pada Vegetasi. Info Teknik. Volume 8 No. 1, Juli 2007 (64-71). 